\title{
Impact of Landfill Site on Real Estate Values in Port Harcourt Metropolis, Nigeria
}

\author{
Prince Chinedu. Mmom \& Mbee Daniel Mbee \\ Department of Geography and Environmental Management,Faculty of Social Sciences, University of Port \\ Harcourt,Port Harcourt, Nigeria.
}

\begin{abstract}
The issue of waste generation and management has become a global challenge to both developed and developing cities of the world. In most cities of the developing world, open landfill is often seen and used as a waste management strategy However, as good as it may appear, presence of landfill in area poses huge economic threat to real estate values. This is worse off, especially if the landfill is un-engineered or not properly managed as the case of landfills in Port Harcourt metropolis. It is therefore the aim of this paper to examine the impact of landfill on real estate values in Port Harcourt metropolis. For this study, 2000 real estate within 500 metres radius from landfill sites were identified and about 600 property owners/agents representing 30 percent of the entire real estate owners were sampled for study. The study thus observed that there is low pricing of property contiguous to landfill.. In most cases, people are less willing to live or acquire properties near landfill locations. Thus property owners near open pits get scared of development for fear of such pits metamorphosing to landfills. Similarly, occupants are unwilling to rent houses near landfill sites thereby demeaning the value of such real estate. In the light of the findings of this study, the paper recommends that government should be proactive in waste management through integrated waste management. Landfills should be properly managed and open pit landfill should be replaced with engineered landfills as to reduce the nuisance of these wastes on the immediate surroundings. Finally, landfills should be located far away from the neighbourhoods/residential areas and proper Environmental Impact Assessment carried out before locating landfills.
\end{abstract}

Key words: Landfill, Real estate Values, waste generation, property owners, Environmental Impact Assessment

\section{Introduction/ Background}

Waste generation is inevitable as long as humans live and they strive to improve their quality of life. Man's activity encapsulates the totality of deriving benefits from raw material while creating left over complexities. The nature of these complexities have been tied to factors as civilization, improved living standards, economic and cultural attributes of man in his environment (Akinola 2000). Complexity in waste is also increasing with biodegradable waste currently accounting for over $50 \%$. This amounts to an annual average approximately 50 milion tons per annum of waste burden on the nation with less than $10 \%$ waste management capacity (Ossai, 2006).

Sadly, the proliferation of dumpsites is alarmingly on the increase with an estimated annual rate of about $0.5-0.7 \%$ and current figures ranging from 0.4 to 0.8 Ton /capital /annum. As individual states of the federation strive towards self sustenance financially, the tendency to industrialize has become pronounced. Industrialization within states has sky-rocketed the volume of urban waste and its complexity has generated comprising heavy industrial wastes (asbestos, cadmium and lead compounds, textile dyes) which require special disposal techniques in designated landfills are consciously disposed off indiscriminately by manufacturers into aquatic bodies and dumpsites via road side drainages and other conveyance channels.

As man generates waste, the challenge of disposal becomes enormous and it has been one of the important aspects of urban management crises in Nigeria. Again, in pursuit of expansion, multinational corporations with global marketing programs, no doubt have changed and increased the overall waste stream. Thomas (2000) noted that waste management which entails disposal is a labour and capital intensive function often consuming $20-50 \%$ of municipal operational budget. This challenge has been accompanied by increased inefficiency in waste disposal as domestically biodegradable wastes (paper, plastics, rags, and food materials) are dumped and burnt in open areas besides individual dwelling and collectively as illegal dumpsites. With over thirty five percent $(35 \%)$ of the Nigerian population living in the cities vis-à-vis a growing urbanization rate of about $7 \%$ per annum and less than ten percent $(10 \%)$ of the city's population enjoying marginal waste management services, health and pollution problems have triggered the thrive of micro-organisms living in the environment.

With a high population of over three million arising from being the hub of petro business in Nigeria the financial aspect of managing dumpsites constitutes a major hindrance for states in the federation. This invariably has fostered a partial or total breakdown of waste management in many towns and cities like Port Harcourt as 
failure to meet acceptable standards have had consequential injury on real estate and the environment (Ogedegbe and Oyedele 2006). The waste disposal and management programs of such a city cannot be over looked vis-à-vis its impact on the environment and predominantly, residential property values.

Port Harcourt metropolis is highly industrialized with a projected average population of between 5-10 million persons (Akinjare. et'al, 2011). The indiscriminate creation of landfills in various parts of the city has distorted environmental aesthetics in those parts and has exposed neighboring property owners, residents and their real estate adjacent to these landfills to detrimental environmental damage. Apart from the environmental damage caused by landfills such as the accumulation of methane gas and possible ground water contamination, residents along landfill axis fear diminishing effects of nearby landfills on their property value. Therefore within the context of this paper the following objectives were set: to investigate the factors that give rise to the proliferation of dumpsites; to evaluate empirically the impact of dumpsites on property values; to access the perception of the residents of the study area on the location of dumpsite in their area; and to examine waste management practices with a view to designing apposite strategies of waste management and recommending same in the study area.

\section{Literature review and Statement of the Problem}

A landfill site (also known as tip, dump or rubbish dump) is a site for the disposal of waste materials by burial and is the oldest form of waste treatment. In another development, real estate means all realty owned as a part of an individual's estate. In essence real estate represents land and all the things permanently attached to it (Brueggeman and Fisher, 2011). Historically, landfills have been the most common methods of organized waste disposal and remain so in many places around the world . Landfills may include internal waste disposal sites (where a producer of waste carries out their own waste disposal at the place of production) as well as sites used by many producers. Many landfills are also used for waste management purposes, such as the temporary storage, consolidation and transfer, or processing of waste material (sorting, treatment, or recycling).

Land filling method is the simplest and widely used waste disposal management method of solid, nonhazardous and non- radioactive wastes. The operation is basically a biological method of waste management. The solid wastes are spread in layers, compacted to the smallest practical volume, and covered by material applied at the end of each operating day. The landfill is built up in units called "cell". It is a disposal site that is carefully selected, designed, constructed and operated to protect the environment and public health. Its merits are low cost, flexible operation and final disposal. On the other hand the disadvantages are that the process is slow, requires large land area and there exists the possibility of leaching of pollutants and toxic metals from the site into the ground water (Narayanan, 2007). There are generically three broad classes of landfill, each of which represents a distinctively different environmental risk profile, viz, Hazardous Waste Landfill; Non-Hazardous Waste Landfill; and Inert Waste Landfill.

Landfill remains the dominant solid waste disposal method in Port Harcourt metropolis (Edeh, 2005). Facts have also been established that the establishment and operation of a landfill in any location creates negative externalities (Akinjare, et'al 2011). Nevertheless, many studies have tried to assess the impacts of landfills on residential property values in adjacent areas. Some studies show no statistical relationship between proximity to a landfill and house price (Gamble, 1982 and Bouvier 2000). Solid waste industry representatives have pointed to these studies as evidence that landfills do not have negative impacts on nearby property values (Parker, 2003).

However, these studies were based on relatively small samples of house sales, so that the sampling variability in the estimated relationship between proximity and house price was high. It is possible that the landfills studied had negative impacts on nearby property values, but that the relationship could not be statistically identified due to small sample sizes. There has not yet been a large-sample study that concretely demonstrated small or non-existent property value impacts from a landfill. Using the approach outlined above, several studies have found that house price was significantly related to landfill proximity. One of the first studies of this type (Havlicek, Richardson and Davies 1971) found that house prices increased $\$ 0.61$ per foot of distance from landfills in Fort Wayne, Indiana. Similar results were obtained for landfills in Minnesota (Nelson, Generoux and Generoux 1992, 1997), Columbus, (Hite, Chern and Hitzhusen 2001), and Toronto (Lim and Missios,2003).

Several of these studies have utilized data sets consisting of more than one landfill size and have concentrated a lot of effort in examining the future trend of waste in Nigeria. Yet there is dearth of work that specifically estimates landfill implications on real estate values in Port Harcourt metropolis. Therefore, in this study we attempt to determine the economic effect of landfill on real estate. Consequently, the research proposes the following questions: what are the factors responsible for landfill location? To what extent does landfill economically affect real estate value in the study area? How do the residents perceive the location of landfills? 


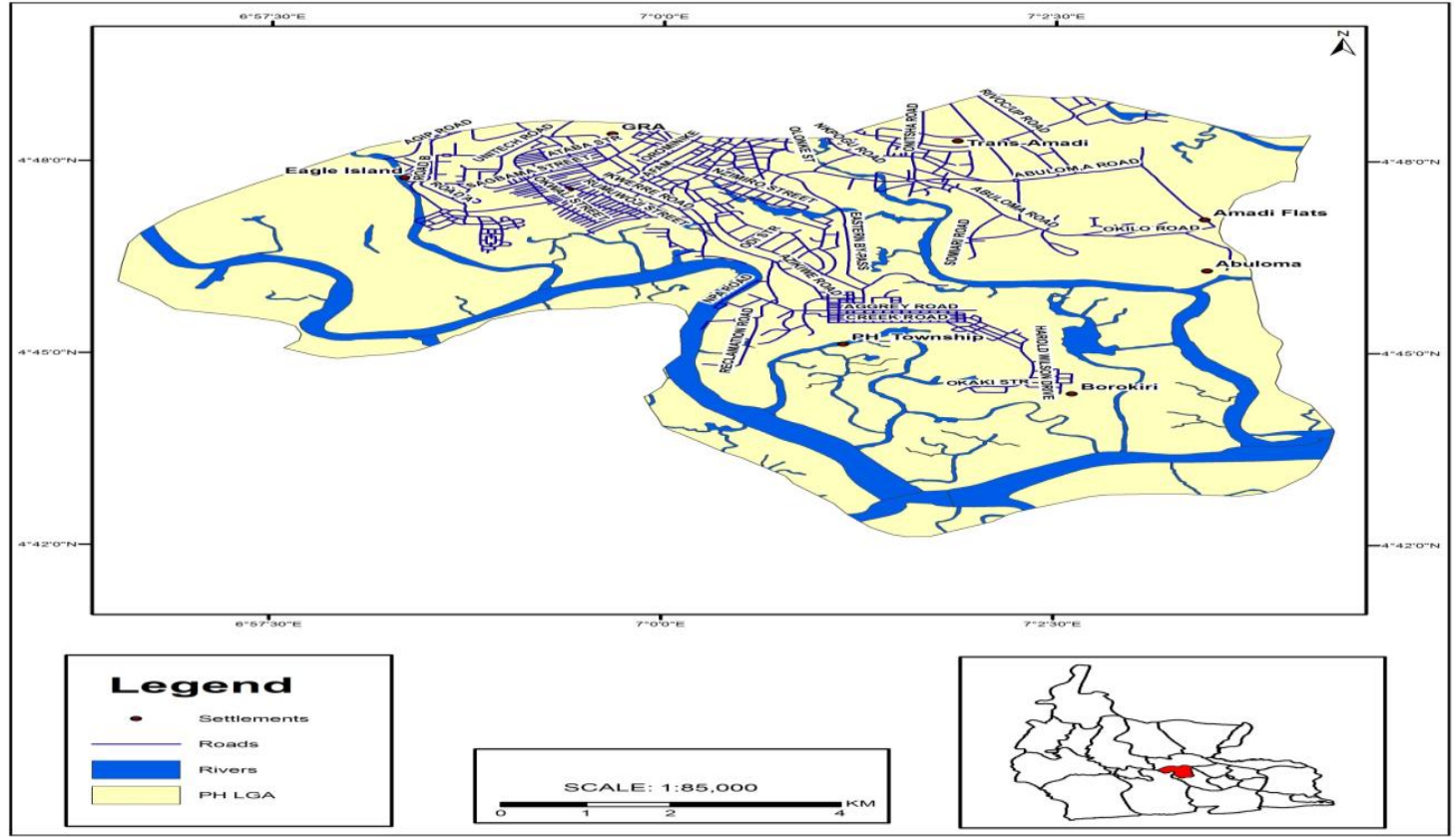

Fig. 1; Map of the study Area

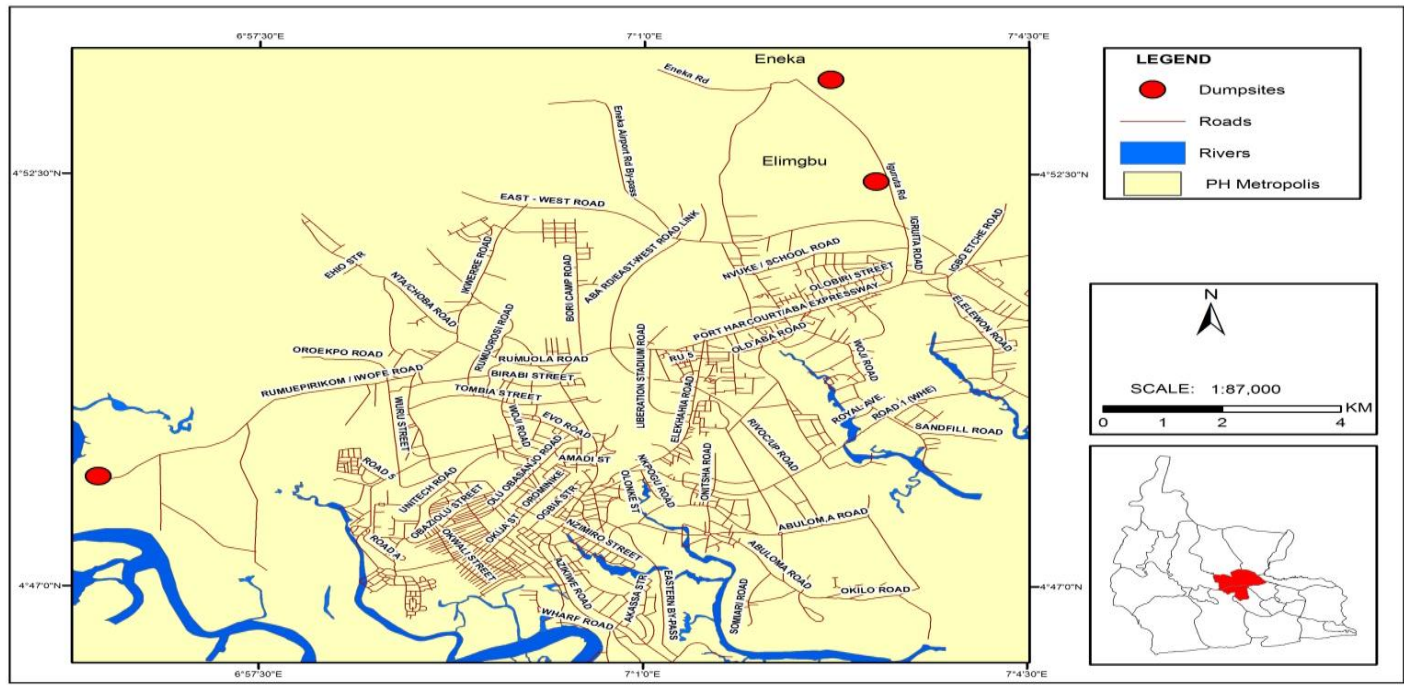

Fig. 2 Map Port Harcourt showing the landfills

\section{Study Methodology/Findings}

In this paper, two data types were used; primary and secondary data. However, primary data were the major and were derived with the help of structured questionnaires and physical observation and inventory taking. The authors considered properties located within 500 metres radius from the dumpsites to assess property value. The three (3) main landfill sites in Port Harcourt were the study focus, that is; Eneka/Runkpoku land fill, Elimgbu and Rumuolumeni landfill sites. From these areas, 30\% of the total properties within this radius were sampled at random. The data generated were analysed using simple statistics in frequency tables as below:

Table 1: Showing sample size

\begin{tabular}{|c|l|c|c|}
\hline S/N & \multicolumn{1}{|c|}{ Landfill Locations } & NO. OF HOUSES & $\begin{array}{c}\text { SAMPLE (30\% } \\
\text { OF TOTAL) }\end{array}$ \\
\hline 1 & Eneka/Rukpoku Rd & 600 & 180 \\
\hline 2 & Elimgbu & 1000 & 300 \\
\hline 3 & Rumuolumeni/Iwofe Rd & 400 & 120 \\
\hline & TOTAL & $\mathbf{2 0 0 0}$ & $\mathbf{6 0 0}$ \\
\hline
\end{tabular}


Source: Researchers' Fieldwork, 2012

Table 1 above shows the number of houses sampled from each of the three landfill areas. From the table, 600 houses were sampled in Eneka/ Rumkpoku landfill sites, 1000 houses from the Elimgbu and 400 houses from the Rumuolumeni/ Iwofe sites respectively, giving a total of 2000 housing units.

Table.2: Presence of Landfill has negative impact on Real Estate

\begin{tabular}{|l|l|c|c|c|}
\hline S/N & Location & \multicolumn{1}{|l|}{ Yes } & No & \multicolumn{1}{l|}{ Total } \\
\hline 1. & Eneka & 180 & 12 & 192 \\
\hline 2. & Elimgbu & 182 & 10 & 192 \\
\hline 3. & Rumuolumeni & 191 & 1 & 192 \\
\hline & Total & 553 & 23 & 576 \\
\hline & Percentage \% & 96.0 & 4.0 & 100 \\
\hline
\end{tabular}

\section{Source: Researchers' fieldwork 2011}

The table above shows that $96.0 \%$ of the respondents view the presence of landfill as negatively affects the value of real estate close to it. Only $4.0 \%$ of the respondents do not see it in that light. Thus, it could be affirmed that presence of landfill sites close to properties have negative impact on real estate.

Table.3: Extent of Effect of negative effect on Real Estate

\begin{tabular}{|l|l|l|c|c|c|c|c|}
\hline S/N & Location & Fairly & Little & Very little & Much & $\begin{array}{l}\text { Very } \\
\text { much }\end{array}$ & Total \\
\hline 1. & Eneka & 20 & - & 10 & 82 & 80 & 192 \\
\hline 2. & Elimgbu & 48 & 2 & - & 74 & 68 & 192 \\
\hline 3. & Rumuolumeni & 10 & - & - & 92 & 90 & 192 \\
\hline & Total & 78 & 2 & 10 & 248 & 238 & 576 \\
\hline & Percentage \% & 13.5 & 0.3 & 1.7 & 43.1 & 41.3 & 100 \\
\hline
\end{tabular}

\section{Source: Researchers' fieldwork 2011}

Table 3 above analyses the extent of the effect of landfill locations on real estate and from the table, $43.1 \%$ of the respondents indicated that the presence of landfill affects property value much, while $41.3 \%$ believe that the effect is very much. Yet $13.5 \%$ consider the extent of the effect to be fair, while $1.7 \%$ and $0.3 \%$ opined that the effect is very little and little respectively. This it could be deduced from this analysis that the presence of landfill sites greatly affects real estate values negatively.

Table.4: Average annual rent range (Naira) of houses with distance from landfill sites ( $¥$ )

\begin{tabular}{|c|c|c|c|c|}
\hline $\mathbf{S} / \mathbf{N}$ & Distance & $\leq \mathbf{2 0 0 m}$ & $\geq 200 \mathrm{~m}-500 \mathrm{~m}$ & $500 \mathrm{~m} \&$ above \\
\hline 1. & 3bedroom flat & $¥ 250,000.00$ & $\approx 280,000.00$ & $\$ 350,000$ \\
\hline 2. & 2bedroom flat & N150,000.00 & $\$ 230,000.00$ & $\approx 280,000.00$ \\
\hline 3. & 1 bedroom flat & N100,000.00 & N110,000.00 & $\$ 150,000.00$ \\
\hline
\end{tabular}

Source: Researcher's fieldwork 2012

Analysis of house rent differentials with distance from landfill sites as presented in table shows that there is a significant reduction in the value of real estate with proximity to land fill sites. For instance, from the table 4 above, a 3 bedroom flat located less 200metres away from the landfill goes for just 250,000.00/annum as against the same grade of 3 bedroom flat located beyond 500 metres from landfill sites that is rented for $350,000.00$. In fact there is a loss of about $100,000.00$ due to the presence of landfill sites. In fact our observation shows that most beautifully furnished apartments close to the landfill sites are unoccupied, even with very attractive prices.

Table 5 Reasons for low property value near the landfill sites

\begin{tabular}{|l|l|l|}
\hline Reasons & Frequency & \% \\
\hline Landfills are poorly managed & 678 & 68.8 \\
\hline Air quality around the landfills is highly (poor) Polluted & 900 & 91.3 \\
\hline Due to poor visual look (Poor aesthetics) & 653 & 66.2 \\
\hline High level of environmental pollution & 742 & 75.3 \\
\hline
\end{tabular}


Impact of Landfill Site on Real Estate Values in Port Harcourt Metropolis, Nigeria

\begin{tabular}{|l|l|l|}
\hline Social \& other reasons & 376 & 38.1 \\
\hline Total & $\mathbf{9 8 5}$ & \\
\hline
\end{tabular}

Source: Authors' field survey, 2012

Analysis of the reason for low property value near to landfill sites shows that poor quality air around landfill sites would have accounted most for low property value as over $90 \%$ of the respondents indicated that in their responses. Similarly, general high level of environmental pollution around the landfills was identifies as a contributory factor, this is followed by poor management of the sites, poor aesthetics and social and other reasons with $75.3 \%, 68.8 \%, 66.2 \%$ and $38.1 \%$ respectively.

Table 6: Factors that determine Landfill location

\begin{tabular}{|l|l|c|c|}
\hline S/N & Factors & Frequency & \% \\
\hline 1. & Availability of Open land & 795 & 80.7 \\
\hline 2. & Government policy & 823 & 83.5 \\
\hline 3. & Population Density & 376 & 38.1 \\
\hline 4 & Accessibility of location & 754 & 76.5 \\
\hline 5 & Distance from neighbourhood & 234 & 23.7 \\
\hline & Total & $\mathbf{9 8 5}$ & \\
\hline
\end{tabular}

Source: Researchers' Fieldwork 2012

Analysis of table 6 above shows above indicates that $83.5 \%$ of the respondents hold government responsible for determining landfill location. In another development, $80.7 \%$, of the population surveyed attributed availability of open space as a major factor of landfill location. Moreso, $76.5 \%$ of the people indicated that the choice of landfill sites depends on the accessibility of the location, while $38.1 \%$ and $23.7 \%$ respectively affirmed that population density and distance from neighbourhood are factors of choice of landfill location.

\section{Summary Of Findings}

The paper found out that landfill, though inevitable in the city of Port Harcourt is deliberated located at any chosen site by Government irrespective of the concern of the people. In most cases, what informed the Government of their decision is that of availability of open spaces in the form of large burrow pits.

Secondly, it was discovered that property values are negatively affected by the presence of these landfills where they are located. Our study shows that this impact is a serious one that has significantly lowered the cost of houses closer to the landfill sites. Most of the houses closer to the landfill sites were discovered to be unoccupied despite their attractive prices, thus corroborating with the findings of Akinjare (2011) that operation of a landfill in any location creates negative externalities such as reduction in the value of real estate around landfills.

Also, the landfill in Port Harcourt city were discovered to be poorly managed, leading to poor environmental conditions and pollution within and around the sites which would have affected the desire to own or rent properties around landfill sites.

Finally, owners of properties around the locations of the dumpsites are not happy with the government for the location of landfills within their neighbourhood, especially those who acquired the properties before the landfills were located there.

\section{Conclusion and Recommendations}

Man's unguided developments and social-economic and political factors have become a serious problem confronting the urban centres in Nigeria, Port Harcourt metropolis inclusive. Indeed landfill is one of the pressing environmental issues that Nigerian cities are plagued with. Landfills have constituted a serious menace to man and his physical environment over the years. A more serious issue of concern here is the deleterious effect of landfills on real estate value. The study which sought to evaluate the implications of landfill on real estate value found that

landfill negatively impacts on the value of properties in Port Harcourt metropolis.

In the light of the foregoing the study therefore suggests as follows:

i. Government should be proactive in managing waste. The agency saddled with the responsibility of managing waste should ensure that landfills are not proliferated in the city. Government should not allow peoples' attitude and interest to decide where a dumpsite will be located in Port Harcourt, but rather, there should be rationality in the choice of landfill locations.

ii. Dumpsites should be sited at the outskirt of residential areas or at the newly developed area of Port Harcourt where a distance of about 500 metres away from away from dumpsites can be implemented by relevant government agency charged with that responsibility. 
iii. Transfer stations should be established at the outskirt of residential areas, which can handle close to 200500 tons of waste per day and serve approximately 6,000-20,000 people. Transfer stations include solid waste services, minimum recycling and collection services.

iv. Residents of Port Harcourt should be educated on the effect of dumping wastes on the streets and other places not earmarked as temporary dumpsites. Inspection and routine checks should be made from time to time and defaulter penalized.

v. There is need for proper management of dumpsites. In fact, government should ensure that the landfills are properly engineered to avoid pollution of the environment (water, land \& Air). Thus, landfills should be properly monitored environmentally and closed up when filled up.

vi. To forestall the proliferation of landfills, Government should embark on aggressive waste recycling to reduce the amount of waste sent to the landfill and finally,

vii. Proper Environmental Impact Assessment should be carried out before landfills are sited in an area.

\section{References}

[1]. Akinola. S. \& Salami. R. (2001) "An Assessment of the Effectiveness of Private Sector Participation Initiatives In Solid Waste Management in Mushin Local Government Area, Lagos State". Nigerian Journal of Social and Educational Research. A Publication of the Nigerian Association of Social and Educational Research, University of Ado-Ekiti.Canback Dangel. Retrieved 2008-08-20.

[2]. Akinjare, S.A,Oloyede, C.A.,Ayedun, O.C Oloke (2011): Price Effects of Landfills on Residential Housing in Lagos, Nigeria. International journal of marketing studies Vol. 3, No. 2; May 2011.

[3]. Bouvier, R.A., J.M. Halstead, K.S. Conway and A.B Manalo,(2000) The Effect of Landfills on Rural Residential Property Values: Some Empirical Analysis, Journal of Regional Analysis and Policy, 2000, 30, 23-37.

[4]. Brueggeman, W.B. and Fisher, J.D. (2011). Real Estate Finance and Investments. Mcgraw-Hill International, Singapore.

[5]. Edeh, E I. (2005): Sustainable Waste Management and the Safety of Solid Waste Workers in Port Harcourt Metropolis, Research Project, Rivers State College of Health Science and Technology.

[6]. Gamble, H. B., R. H. Downing, J. S. Shortle and D. J. Epp, Effects of Solid Waste Disposal Sites on Community Development and Residential Property Values, Final Report for The Bureau of Solid Waste Management (Department of Environmental Resources, Commonwealth of Pennsylvania), 1982.

[7]. Havlicek, J. Jr., R. Richardson and L. Davies, Measuring the Impacts of Solid Waste Disposal Site Location on Property Values, Urban Economics Report \#65, University of Chicago, 1971.

[8]. Hite, D., W. Chern, F. Hitzusen and A. Randall, Property-Value Impacts of an Environmental Disamenity: The Case of Landfills, Journal of Real Estate Finance and Economics, 2001, 22, 185-202.

[9]. Lim, J. S., and P. Missios, Does Size Really Matter? Landfill Scale Impacts on Property Values, Unpublished Working Paper, Department of Economics, Ryerson University, Toronto, 2003.

[10]. Narayanan, P. (2006). Environmental Pollution, Principles, Analysis and Control. CBS Publishers and Distributors, News Delhi.

[11]. Nelson, A.C., J. Genereux and M.M. Genereux (1992). Price Effects of Landfills on House Values, Land Economics, 68, 359-65.

[12]. Nelson, A.C., J. Genereux and M.M. Genereux (1997) Price Effects of Landfills on Different House Value Strata, Journal of Urban Planning and Development, 123, 59-67.

[13]. Ogedegbe \& Oyedele. (2006). Effect of Waste Management on Property Values in Ibadan Nigeria. Journal of Land Use and Development Studies, Vol. 2, No. 1, 2006.

[14]. Ossai, R.M. (2006). Moving Solid Waste Management into the 21 st century in Nigeria. Presented at the $6^{\text {th }}$ National Council on Environment Meeting held at Katsina State Secretariat, Katsina 13th- 17th, November, 2006.

[15]. Owei, O.B. (1997). A study of Valuation and Pricing Practices in the Residential Property Market in Lagos Metropolis. Unpublished M.Sc thesis, Obafemi Awolowo University, Ile-Ife.

[16]. Parker, B.J. (2003). Solid Waste Landfills and Residential Property Values. White Paper, National Solid Wastes Management Association, Washington, DC, 6.

[17]. Reichert, A.K., M. Small and S. Mohanty (1992). The Impact of Landfills on Residential Property Values, The Journal of Real Estate Research, 7, 297-314.

[18]. Rosen, S. 1974. "Hedonic Prices and Implicit Markets: Product Differentiation in Pure Competition.” Journal of Political Economy 82:34-55.

[19]. Thomas. L. (2000). Brief History of Solid Waste Management. Written for the California Department of Health Services. 